\title{
Effect of a herbal essential oil mixture on growth and internal organ weight of broilers from young and old breeder flocks
}

\author{
M. Çabuk ${ }^{1 \#}$, M. Bozkurt ${ }^{2}$, A. Alçiçek ${ }^{3}$, Y. Akbaş $^{3}$ and K. Küçükyılmaz ${ }^{2}$ \\ ${ }^{1}$ Department of Poultry Science, Akhisar Vocational School of Celal Bayar University, Manisa-Turkey \\ ${ }^{2}$ Poultry Research Institute, Erbeyli, Aydın-Turkey \\ ${ }^{3}$ Department of Animal Science, Agricultural Faculty of Ege University, Bornova, Izmir-Turkey
}

\begin{abstract}
The aim of the present study was to examine the effects of a herbal essential oil mixture on the performance of broilers produced by a young $(30 \mathrm{wk})$ or an old breeder $(80 \mathrm{wk})$ flock. One thousand and eight unsexed day-old broiler chicks (Ross-308) originating from the two breeder flocks were randomly allocated to three treatment groups of 336 birds each. Dietary treatments were: a control and two diets containing $24 \mathrm{mg} / \mathrm{kg}$ or $48 \mathrm{mg} / \mathrm{kg}$ of an essential oil mixture. There were no significant effects of dietary treatment on body weight of the broilers at 21 and 42 days. The effect of the age of the parents did not have a significant effect on body weight of the broilers at 21 and 42 days of age. Up to 21 days the feed intake of broilers from young breeders was reduced significantly as a result of the inclusion of the essential oil mixture in their diets, and a significant improvement in feed conversion ratio was recorded in these birds. Difference in regression coefficients for feed intake and feed conversion ratio between broilers from young and old breeder flocks was significant. Carcass yield and some internal organ weights such as the liver, pancreas, proventriculus, gizzard and small intestine were not affected by the addition of the essential oil mixture to the diet. Inclusion of essential oil mixture to the diet decreased mortality significantly at 21 days.
\end{abstract}

Keyword: Herbal essential oils, broiler, performance, organ weight, breeder age

${ }^{\#}$ Corresponding author. E-mail: metin.cabuk@deu.edu.tr

\section{Introduction}

Antibiotic feed additives have been used for more than 50 years to enhance growth performance and to prevent disease in livestock feeding environments. However, the current trend is to look for alternatives to antibiotic feed additives because of public concern about antibiotic residues in animal products and the potential evolving of antibiotic resistant bacteria. As a consequence, new commercial additives of plant origin, considered to be natural products that the consumer would accept, have been proposed to animal producers. The chemical components of most essential oils from plants are generally recognized as safe, and are used commonly in the food industry (Varel, 2002). Essential oils derived from herbs have been shown to have antimicrobial effects (Dorman \& Deans, 2000). Their antimicrobial mode of action consists of interactions with the cell membranes of microorganisms by changing permeability for cations such as $\mathrm{H}^{+}$and $\mathrm{K}^{+}$(Ultee et al., 1999). Moreover, there is evidence to suggest that herbs, spices and various plant extracts have appetizing and digestion-stimulating properties and antimicrobial effects (Gill, 1999; Langhout, 2000; Madrid et al., 2003; Alçiçek et al., 2004; Zhang et al., 2005). The improvement in feed efficiency achieved with essential oil mixtures could be attributed to their positive effects on nutrient digestibility, as reported by Langhout (2000), Madrid et al. (2003), Hernandez et al. (2004) and Jamroz et al. (2005).

Breeder age was found to influence broiler performance differently during the various phases of the growing period (Peebles et al., 1999a; b). Moreover, Peebles et al. (1999a) showed that body weight of broilers from 51-wk old breeders was significantly higher than that of broilers from 63 -wk old breeders.

Information in the literature regarding the effects of added dietary essential oils and breeder age throughout production on performance and slaughter yield is lacking. The objective of the present study was to examine the effect of dietary supplementation of a herbal essential oil mixture (EOM) on growth performance of broilers originating from young or old breeder flocks. 


\section{Materials and Methods}

One thousand and eight unsexed day-old broiler chicks (Ross-308) originating from young (30 wks of age) and old ( 80 wks of age) breeder flocks were allocated randomly to three dietary treatment groups, viz. a control and the diet containing 24 or $48 \mathrm{mg} / \mathrm{kg}$ of an EOM. Each treatment consisted of eight replications with 42 birds per replicate. Each group contained 168 broilers from young and 168 broilers from old broiler breeder flocks. The commercial essential oil mixture ${ }^{\mathrm{TM}}$ (Herba Ltd. Co. İzmir-Turkey) consisted of six different essential oils derived from selected herbs growing in Turkey, viz. oregano oil (Origanum sp.), laurel leaf oil (Laurus nobilis L.), sage leaf oil (Salvia triloba L.), myrtle leaf oil (Myrtus communis), fennel seed oil (Foeniculum vulgare), citrus peel oil (Citrus sp). Hydrodistillation was used to extract the essential oils.

Table 1 Ingredients and chemical composition of the experimental diets (as fed)

\begin{tabular}{|c|c|c|c|}
\hline & \multicolumn{3}{|c|}{ Treatments } \\
\hline & Control & $24 \mathrm{mg}$ EOM/kg diet & $48 \mathrm{mg} \mathrm{EOM} / \mathrm{kg}$ diet \\
\hline \multicolumn{4}{|l|}{ Ingredients $(\mathrm{kg} / 1000 \mathrm{~kg})$} \\
\hline Maize & 553.2 & 552.3 & 552.3 \\
\hline Soyabean meal (48\% CP) & 171.0 & 171.5 & 171.5 \\
\hline Full fat soyabean meal & 125.3 & 124.5 & 124.5 \\
\hline Maize gluten & 50.0 & 50.5 & 50.5 \\
\hline Sunflower meal (39\% CP) & 50.0 & 49.1 & 49.1 \\
\hline Vegetable oil (Soyabean oil) & 15.0 & 15.6 & 15.6 \\
\hline Dicalcium phosphate & 12.7 & 12.7 & 12.7 \\
\hline Ground limestone & 9.2 & 9.2 & 9.2 \\
\hline Salt & 3.6 & 3.6 & 3.6 \\
\hline Vitamin premix* & 2.5 & 2.5 & 2.5 \\
\hline Mineral premix** & 1.0 & 1.0 & 1.0 \\
\hline DL-methionine & 1.7 & 1.7 & 1.7 \\
\hline L-lysine & 2.3 & 2.3 & 2.3 \\
\hline Antioxidant & 1.0 & 1.0 & 1.0 \\
\hline Anticoccidial agent & 0.5 & 0.5 & 0.5 \\
\hline Phytase (Natuphos) & 1.0 & 1.0 & 1.0 \\
\hline EOM $(24 \mathrm{~g} / \mathrm{kg})$ premix & - & 1.0 & - \\
\hline EOM $(48 \mathrm{~g} / \mathrm{kg})$ premix & - & - & 1.0 \\
\hline Total & 1000 & 1000 & 1000 \\
\hline \multicolumn{4}{|l|}{ Composition (analysed) (g/kg) } \\
\hline Dry matter & 892.5 & 906.3 & 902.1 \\
\hline Crude protein $(\mathrm{CP})$ & 222.4 & 218.9 & 220.3 \\
\hline Ether extract & 64.0 & 62.3 & 60.4 \\
\hline Crude fibre & 37.3 & 39.1 & 39.8 \\
\hline Crude ash & 53.8 & 55.4 & 56.8 \\
\hline Starch & 352.6 & 358.3 & 361.2 \\
\hline Sugar & 52.3 & 46.1 & 51.7 \\
\hline Total calcium & 10.2 & 11.4 & 10.3 \\
\hline Total phosphorus & 7.0 & 7.3 & 6.9 \\
\hline Lysine ${ }^{\neq}$ & 12.0 & 12.0 & 12.0 \\
\hline Met. + Cys. $^{\neq}$ & 9.2 & 9.2 & 9.2 \\
\hline Available phosphorus ${ }^{\ddagger}$ & 4.5 & 4.5 & 4.5 \\
\hline Metabolisable energy $(\mathrm{MJ} / \mathrm{kg})^{\neq}$ & 13.09 & 12.98 & 13.07 \\
\hline
\end{tabular}

EOM - essential oil mixture; ${ }^{\neq}$calculated

* Vitamin premix (/kg diet): Vitamin A - $12000 \mathrm{IU}$; vitamin $\mathrm{D}_{3}-1500 \mathrm{IU}$; vitamin $\mathrm{E}$ - $30 \mathrm{mg}$; vitamin $\mathrm{K}_{3}-5 \mathrm{mg}$; vitamin $\mathrm{B}_{1}$ - $3 \mathrm{mg}$; vitamin $\mathrm{B}_{2}$ - $6 \mathrm{mg}$; vitamin $\mathrm{B}_{6}-5 \mathrm{mg}$; vitamin $\mathrm{B}_{12}-0.03 \mathrm{mg}$; nicotine amid - $40 \mathrm{mg}$; calcium-Dpantothenate - $10 \mathrm{mg}$; folic acid - $0.75 \mathrm{mg}$; D-biotin - $0.075 \mathrm{mg}$; choline chloride $375 \mathrm{mg}$; antioxidant - $10 \mathrm{mg}$ ** Mineral premix (mg/kg diet): $\mathrm{Mn}-80 ; \mathrm{Fe}-80 ; \mathrm{Zn}-60 ; \mathrm{Cu}-8 ; \mathrm{I}-0.5 ; \mathrm{Co}-0.2 ; \mathrm{Se}-0.15$ 
The experimental diets were in mash form and formulated to be isoenergetic and isonitrogenous. Diets and water were provided ad libitum. A photoperiod of $24 \mathrm{~h} / \mathrm{d}$ was maintained. The body weights of the birds were measured individually and feed intake per pen was recorded. Feed conversion ratio (FCR) was adjusted for weight of chicks on the first day of the study. Mortality was recorded and was used to adjust total number of birds to determine total feed intake per bird. At the end of the experimental period 16 male birds (eight from old and eight from young parent flocks) of similar body weight were selected from each treatment group, weighed and slaughtered to determine carcass yield and organ weights. Standard techniques were used to determine the nutrient composition of the diets (Naumann \& Bassler, 1993). The diets were also analyzed for starch, sugar, total calcium and phosphorus, according to chemical analytical methods recommended by the Association of German Agricultural Analysis and Research Institutes (VDLUFA) (Naumann \& Bassler, 1993). Metabolisable energy content of the diets was calculated based on chemical composition (Anonymous, 1991). Feed ingredients and chemical composition of the diets are presented in Table 1.

The data were analyzed using regression analysis to understand the effects of different levels of the essential oil mixture (EOM $=0,24$ and $48 \mathrm{mg} / \mathrm{kg}$ diet) on several traits. Firstly, simple regression analyses were carried out for broilers from young and old breeders separately and both broilers. Secondly, an analysis was applied to compare intercepts and regression coefficients obtained from two regression equations for the groups (young and old). To do this analysis, a dummy variable called "constdiff" that is coded 1 for old and 0 for broilers from young breeder flocks and another variable "slopediff" that is the product of "constdiff" were created. Then "constdiff", EOM and "slopediff" effects were used as predictors in the regression equation. In the output of this final regression analysis, the constant indicates the intercept for broilers from young breeders; regression coefficients for "constdiff", EOM and "slopediff" represent the difference between the intercepts for broilers from old and young breeders; slope for broilers from young breeders (omitted group) and the difference between the slopes for broilers from old and young breeders, respectively. Statistical analysis was undertaken using SPSS (Norusis, 1993).

\section{Results and Discussion}

Means of body weight, feed intake, feed conversion ratio and mortality of the broilers are given in Table 2. Regression analysis results are presented in Table 3.

Table 2 The effects of the essential oil mixture (EOM) on body weight, feed intake, feed conversion ratio (FCR) and mortality of the broilers from young and old breeder flocks

\begin{tabular}{|c|c|c|c|c|c|c|c|c|c|}
\hline \multirow[b]{2}{*}{ Age, day } & \multicolumn{3}{|c|}{$\begin{array}{c}\text { Body weight } \\
\text { g }\end{array}$} & \multicolumn{2}{|c|}{$\begin{array}{c}\text { Feed intake } \\
\mathrm{g}\end{array}$} & \multicolumn{2}{|c|}{$\begin{array}{c}\mathrm{FCR} \\
\mathrm{g} \text { feed/g gain }\end{array}$} & \multicolumn{2}{|c|}{$\begin{array}{c}\text { Mortality } \\
\% \\
\end{array}$} \\
\hline & $1 \mathrm{~d}$ & $21 \mathrm{~d}$ & $42 \mathrm{~d}$ & $21 \mathrm{~d}$ & $42 \mathrm{~d}$ & $21 \mathrm{~d}$ & $42 \mathrm{~d}$ & $21 \mathrm{~d}$ & $42 \mathrm{~d}$ \\
\hline \multicolumn{10}{|l|}{ Treatments: } \\
\hline Control & 38.7 & 704.9 & 2281.3 & 1077.5 & 4184.3 & 1.62 & 1.87 & 2.38 & 3.57 \\
\hline 24 mg EOM/kg & 38.5 & 701.9 & 2278.8 & 1016.3 & 4023.6 & 1.53 & 1.80 & 0.60 & 0.89 \\
\hline $48 \mathrm{mg}$ EOM/kg & 38.8 & 706.4 & 2282.4 & 1041.0 & 3976.8 & 1.56 & 1.77 & 1.19 & 1.78 \\
\hline s.e.m. pooled & 0.37 & 6.91 & 16.64 & 6.23 & 29.42 & 0.015 & 0.025 & 0.343 & 0.534 \\
\hline Young & 36.1 & 701.3 & 2305.9 & 1024.8 & 4033.3 & 1.54 & 1.78 & 1.19 & 1.78 \\
\hline Old & 41.3 & 707.6 & 2255.9 & 1065.0 & 4089.5 & 1.60 & 1.85 & 1.60 & 2.38 \\
\hline s.e.m. pooled & 0.29 & 5.41 & 13.58 & 5.09 & 24.02 & 0.012 & 0.021 & 0.280 & 0.44 \\
\hline
\end{tabular}

In general, EOM supplementation of the diet did not affect $(\mathrm{P}>0.05)$ body weight of the broilers at 21 and 42 days of age (Table 3). This result is similar to the finding of Madrid et al. (2003) who studied the effect of a plant extract (blend of oregano, cinnamon and pepper essential oil) on broiler performance. Our findings are in agreement with those of Botsoglou et al. (2004) who reported that the supplementation of essential oils to a diet had no beneficial effect on body weight. A similar result was observed by Jamroz et al. 
(2005) who noted that a plant extract included in a broiler diet did not improve the body weight of broilers. Moreover, Sarica et al. (2005) reported that the addition of thyme powder to a broiler diet had no significant positive effect on body weight. In contrast, positive effects of dietary essential oils on body weight were observed by Alçiçek et al. (2003) and Denli et al. (2004). Hernandez et al. (2004) also found that the addition of two plant extracts to a broiler diet significantly improved broiler body weight at 35 days of age. Moreover, Jamroz et al. (2003) found that the inclusion of 150 or $300 \mathrm{mg} / \mathrm{kg}$ of a plant extract containing capsaicin, carvacrol and cinnamicaldehyde in a diet improved body weight by 5.4 and $8.1 \%$, respectively.

Table 3 Regression analysis results of dietary inclusion of the essential oil mixture (EOM) on body weight, feed intake, feed conversion ratio (FCR) and mortality of the broilers from young and old breeder flocks

\begin{tabular}{|c|c|c|c|c|c|c|c|c|c|}
\hline \multirow{2}{*}{$\begin{array}{l}\text { Parent } \\
\text { age }\end{array}$} & \multirow{2}{*}{$\mathrm{Y}=\mathrm{A}+\mathrm{B} * \mathrm{EOM}$} & \multicolumn{2}{|c|}{$\begin{array}{c}\text { Body weight } \\
\text { g }\end{array}$} & \multicolumn{2}{|c|}{$\begin{array}{c}\text { Feed intake } \\
\mathrm{g}\end{array}$} & \multicolumn{2}{|c|}{$\begin{array}{c}\text { FCR } \\
\mathrm{g} \text { feed/g gain }\end{array}$} & \multicolumn{2}{|c|}{$\begin{array}{c}\text { Mortality } \\
\% \\
\end{array}$} \\
\hline & & $21 \mathrm{~d}$ & $42 \mathrm{~d}$ & $21 \mathrm{~d}$ & $42 \mathrm{~d}$ & $21 \mathrm{~d}$ & $42 \mathrm{~d}$ & $21 \mathrm{~d}$ & $42 \mathrm{~d}$ \\
\hline \multirow[t]{2}{*}{ Young } & A & $698 * *$ & $2299 * *$ & $1065 * *$ & $4130 * *$ & $1.609 * *$ & $1.827 * *$ & $2.182 * *$ & $3.867 * *$ \\
\hline & B & 0.124 & 0.148 & $-1.667 *$ & $-4.036 *$ & $-0.003 *$ & -0.0019 & -0.025 & -0.062 \\
\hline \multirow[t]{2}{*}{ Old } & A & $711 * *$ & $2262 * *$ & $1062 * *$ & $4200 * *$ & $1.587 * *$ & $1.896 * *$ & $1.785 * *$ & $2.082 *$ \\
\hline & B & -0.105 & -0.249 & 0.146 & $-4.609 * *$ & 0.0004 & -0.0019 & -0.025 & -0.012 \\
\hline \multirow[t]{2}{*}{ General } & A & $705 * *$ & $2281 * *$ & $1063 * *$ & $4165 * *$ & $1.598 * *$ & $1.862 * *$ & $1.983 * *$ & $2.975 * *$ \\
\hline & $\mathrm{B}$ & 0.016 & -0.058 & -0.760 & $-4.323 * *$ & -0.0012 & $-0.0019 *$ & $-0.025 *$ & -0.037 \\
\hline
\end{tabular}

A - the intercept (value of trait when $\mathrm{EOM}=0$ )

$\mathrm{B}$ - slope of the straight line (change in the trait for a unit change in EOM)

$* \mathrm{P}<0.05 ; * * \mathrm{P}<0.01$

Table 4 Comparison of intercepts and regression coefficients obtained from two regression equations for the broilers from young and old breeder flocks for body weight, feed intake, feed conversion ratio (FCR) and mortality of the broilers

\begin{tabular}{|c|c|c|c|c|c|c|c|c|}
\hline & \multicolumn{2}{|c|}{$\begin{array}{c}\text { Body weight } \\
\mathrm{g}\end{array}$} & \multicolumn{2}{|c|}{$\begin{array}{c}\text { Feed intake } \\
\mathrm{g}\end{array}$} & \multicolumn{2}{|c|}{$\begin{array}{c}\text { FCR } \\
\mathrm{g} \text { feed/g gain }\end{array}$} & \multicolumn{2}{|c|}{$\begin{array}{c}\text { Mortality } \\
\%\end{array}$} \\
\hline & $21 \mathrm{~d}$ & $42 \mathrm{~d}$ & $21 \mathrm{~d}$ & $42 \mathrm{~d}$ & $21 \mathrm{~d}$ & $42 \mathrm{~d}$ & $21 \mathrm{~d}$ & $42 \mathrm{~d}$ \\
\hline A & $698 * *$ & $2299 * *$ & $1065 * *$ & $4130 * *$ & $1.609 * *$ & $1.827 * *$ & $2.182 * *$ & $3.867 * *$ \\
\hline B1 & 13.015 & -37.104 & -3.333 & 69.667 & -0.022 & 0.068 & -0.397 & -1.785 \\
\hline B2 & 0.124 & 0.148 & $-1.667 * *$ & $-4.036 * *$ & $-0.003 * *$ & -0.002 & -0.025 & $-0.062 *$ \\
\hline B3 & -0.229 & -0.396 & $1.812 * *$ & -0.573 & $0.003 *$ & 0.000 & 0.000 & 0.050 \\
\hline $\begin{array}{l}\mathrm{Y}= \\
\mathrm{A}- \\
\mathrm{B} 1 \\
\mathrm{~B} 2 \\
\mathrm{~B} 3 \\
* \mathrm{P}\end{array}$ & $\begin{array}{l}\mathrm{B} 1 * \mathrm{COl} \\
\text { ntercept } \\
\text { differen } \\
\text { be for br } \\
\text { differen } \\
5 ; * * \mathrm{P}\end{array}$ & $\begin{array}{l}\mathrm{IFF}+\mathrm{B} 2 \\
\text { iler from } \\
\text { veen the } \mathrm{i} \\
\text { om young } \\
\text { veen the } \mathrm{s}\end{array}$ & $\begin{array}{l}\mathrm{I}+\mathrm{B} 3 * \mathrm{SL} \\
\mathrm{g} \text { breeders } \\
\text { pts for bro } \\
\text { der } \\
\text { for broiler }\end{array}$ & $\begin{array}{l}\text { DIFF } \\
\text { rom old an } \\
\text { old and fo }\end{array}$ & $\begin{array}{l}\text { r young br } \\
\text { oilers from }\end{array}$ & ers & & \\
\hline
\end{tabular}

In the present study feed intakes and feed conversion ratios were significantly influenced by the addition of EOM to the diet at the 42 days of age stage. These results also differed between broilers from young and old breeders. A decrease $(\mathrm{P}=0.014)$ in feed intake $(-1.667 \mathrm{~g})$ for broilers originating from young breeder during the first three weeks was observed for a one unit increase in EOM. However, the response (0.146) was positive and not significant $(\mathrm{P}=0.612)$ for broilers originating from the old breeder flock. The constant terms in the regression equation were not different (-3.333) for broilers originating from young and old breeders, although the difference in regression coefficient (1.812) was significant, indicating that they 
responded differently to the addition of EOM to the diet. In response to one mg increase in EOM, a significant decrease $(-4.323 \mathrm{~g})$ in feed intake during the first six weeks was estimated. This decline was similar for broilers originating from young (-4.036) and old (-4.609) breeder flocks. Similarly, the addition of EOM to the diet improved FCR. For broilers originating from young breeders, FCR decreased $(\mathrm{P}=0.05)$ by -0.0027 during the first three weeks in response to one $\mathrm{mg}$ increase in EOM. However, the regression coefficient $(0.0004)$ was not significant $(\mathrm{P}=0.27)$ for broilers originating from old breeders. The constant terms did not differ significantly $(\mathrm{P}=0.581)$ and was -0.022 , although the difference in regression coefficients $(0.003)$ was significant $(\mathrm{P}=0.022)$. The response to one $\mathrm{mg}$ increase in EOM, FCR at 42 days in broilers originating from young and old breeders did not differ $(\mathrm{P}>0.08)$ in separate analyses. However, the relationship was found to differ significantly $(\mathrm{P}=0.04)$ in the overall analysis.

Our findings on feed intake and feed conversion are also in agreement with those of Lee et al. (2003) who studied carvacrol from oregano, those of Madrid et al. (2003) who studied the effect of plant extract and those of Alcicek et al. (2004) who used $48 \mathrm{mg} / \mathrm{kg}$ of an essential oil mixture in the diet of broiler. Denli et al. (2004) reported that the addition of thyme essential oil to a quail diet improved feed conversion ratio. Furthermore, Halle et al. (2004) noted that the addition of oregano and its essential oil reduced daily feed intake of broilers and significantly improved FCR. Recently, Jamroz et al. (2005) used a maize-soyabean meal diet and a wheat-barley diet with male broiler chickens to evaluate the effect of carvacrol, capsaicin and cinnamaldehyde. The authors noted that the FCR was improved by $4.2 \%$ in chicks on the maize diets and $2.0 \%$ when receiving wheat-barley diets. The improvement in feed efficiency achieved with essential oil mixtures could be attributed to their positive effects on nutrient digestibility, as reported by Langhout (2000), Madrid et al. (2003) and Hernandez et al. (2004). In contrast to our result, Lee et al. (2003), Botsoglou et al. (2004) and Hernandez et al. (2004) reported that addition of plant extracts or essential oils to the diet had no beneficial effect on feed intake or FCR.

Body weight of broilers at 21 and 42 days was not significantly affected by parent age (Tables 2 and $3)$. Differences between regression coefficients for broilers originating from young (0.124 and 0.148) and old breeders (-0.105 and -0.249 at 21 and 42 days, respectively) were not significant (Table 3 ). This result is similar to the finding of Reis et al. (1997) who reported no effect of broiler breeder age on broiler weights at slaughter age. In contrast to our result, Peeples et al. (1999a) reported that body weight at 21 days of age was significantly higher in broilers from 35-week old breeders than those from 51- and 63- week old breeders. Feed intake was significantly affected by parent age at day 21 . Broilers originating from young breeders had lower feed intakes than those from old broiler breeders, but parent age had no significant effect on feed intake at 42 days (Table 4). FCR was significantly influenced by parent age at 21 days. Thus, broilers originating from young breeders had better FCR than those from old breeders. Mortality of the broilers was affected $(\mathrm{P}=0.044)$ by supplementation of EOM in the general analysis, and decreased mortality at 21 days $(\mathrm{P}<0.05)$.

Table 5 The effect of essential oil mixture (EOM) on relative weight ( $\%$ body weight) of some internal organs of broilers from young and old breeder flocks at 42 days of age

\begin{tabular}{lcccccc}
\hline & $\begin{array}{c}\text { Carcass yield } \\
\%\end{array}$ & $\begin{array}{c}\text { Liver } \\
\%\end{array}$ & $\begin{array}{c}\text { Pancreas } \\
\%\end{array}$ & $\begin{array}{c}\text { Proventriculus } \\
\%\end{array}$ & $\begin{array}{c}\text { Gizzard } \\
\%\end{array}$ & $\begin{array}{c}\text { Small intestine } \\
\%\end{array}$ \\
\hline Treatments: & & & & & & \\
$\quad$ Control & 72.02 & 1.83 & 0.249 & 0.286 & 1.50 & 2.67 \\
$24 \mathrm{mg} \mathrm{EOM} / \mathrm{kg}$ & 72.54 & 1.87 & 0.251 & 0.300 & 1.51 & 2.65 \\
$48 \mathrm{mg} \mathrm{EOM} / \mathrm{kg}$ & 72.89 & 1.83 & 0.256 & 0.281 & 1.49 & 2.62 \\
s.e.m. pooled & 0.34 & 0.35 & 0.009 & 0.012 & 0.04 & 0.07 \\
Young & & & & & & \\
Old & 72.30 & 1.84 & 0.252 & 0.294 & 1.55 & 2.61 \\
s.e.m. pooled & 72.66 & 1.85 & 0.253 & 0.284 & 1.46 & 2.68 \\
& 0.277 & 0.028 & 0.007 & 0.010 & 0.04 & 0.06 \\
\hline
\end{tabular}


Relative weights of the carcass, liver, pancreas, proventriculus, gizzard and small intestine weight were not affected by dietary treatment (Table 5). Our findings are in agreement with the results of Hernandez et al. (2004) who found no differences in gizzard, liver and pancreas weights of broiler chickens fed diet containing an essential oil extract from oregano, cinnamon and pepper and a labiatae extract from sage, thyme and rosemary. Similar results were observed by Jamroz et al. (2005) who used essential oils in broiler diets based on maize and locally grown cereals. In contrast, Denli et al. (2004) indicated that inclusion of thyme and black seed essential oil increased intestinal weight and intestinal length in quail. There was no significant change in relative weights of carcass, liver, pancreas, proventriculus, gizzard or small intestine weight for increments in EOM (Table 6). Since this result is similar for broiler originating from young and old breeders, only overall results are presented in Table 6. Differences in regression model parameters between young and old broilers were also not significant (Table 7).

Table 6 Regression analysis results of effect of the essential oil mixture (EOM) on relative weight (\% body weight) of some internal organs of broilers at 42 days of age

\begin{tabular}{lcccccc}
\hline $\mathrm{Y}=\mathrm{A}+\mathrm{B} * \mathrm{EOM}$ & $\begin{array}{c}\text { Carcass } \\
\text { yield } \%\end{array}$ & $\begin{array}{c}\text { Liver } \\
\%\end{array}$ & $\begin{array}{c}\text { Pancreas } \\
\%\end{array}$ & $\begin{array}{c}\text { Proventriculus } \\
\%\end{array}$ & $\begin{array}{c}\text { Gizzard } \\
\%\end{array}$ & $\begin{array}{c}\text { Small } \\
\text { intestine } \%\end{array}$ \\
\hline $\mathrm{A}$ & & & & & & \\
$\mathrm{B}$ & $72.04 * *$ & $1.842 * *$ & $0.249 * *$ & $0.292 * *$ & $1.503 * *$ & $2.669 * *$ \\
& $0.018 \mathrm{~ns}$ & $0.00003 \mathrm{~ns}$ & $0.0001 \mathrm{~ns}$ & $-0.0001 \mathrm{~ns}$ & $-0.00008 \mathrm{~ns}$ & $0.001 \mathrm{~ns}$ \\
\hline
\end{tabular}

A - the intercept (value of trait when $\mathrm{EOM}=0$ )

$\mathrm{B}$ - slope of the straight line (change in the trait for a unit change in EOM)

$* \mathrm{P}<0.05 ; * * \mathrm{P}<0.01 ; \mathrm{ns}-$ not significant

Table 7 Probabilities for significances of the model parameters ${ }^{1}$ to compare the intercepts and regression coefficients obtained from two regression equations for broilers from young and old breeders for relative weight of some internal organs of broilers at 42 days of age

\begin{tabular}{lcccccc}
\hline & $\begin{array}{c}\text { Carcass yield } \\
\%\end{array}$ & $\begin{array}{c}\text { Liver } \\
\%\end{array}$ & $\begin{array}{c}\text { Pancreas } \\
\%\end{array}$ & $\begin{array}{c}\text { Proventriculus } \\
\%\end{array}$ & $\begin{array}{c}\text { Gizzard } \\
\%\end{array}$ & $\begin{array}{c}\text { Small intestine } \\
\%\end{array}$ \\
\hline A & 0.000 & 0.000 & 0.000 & 0.000 & 0.000 & 0.000 \\
B1 & 0.337 & 0.865 & 0.901 & 0.500 & 0.069 & 0.204 \\
B2 & 0.104 & 0.802 & 0.785 & 1.000 & 0.526 & 0.317 \\
B3 & 0.625 & 0.742 & 0.923 & 0.776 & 0.340 & 0.330
\end{tabular}

\footnotetext{
${ }^{1} \mathrm{Y}=\mathrm{A}+\mathrm{B} 1 * \mathrm{CONSTDIFF}+\mathrm{B} 2 * \mathrm{EOM}+\mathrm{B} 3 * \mathrm{SLOPEDIFF}$

$\mathrm{A}$ - the intercept for broilers from young breeder

B1 - the difference between the intercepts for broilers from old and young breeders

B2 - slope for young breeders

B3 - the difference between the slopes for broilers from old and young breeders
}

\section{Conclusion}

Supplementation of a mixture of herbal essential oils to the diet reduced feed intake and improved FCR. These effects were different for broilers originating from young vs. old breeder flocks at 21 days of age. Broilers originating from young breeders had better FCR than those from old breeders when the essential oil mixture was added to the diet. The herbal essential oil mixture may be considered a potential growth promoter. However, more trials are needed to determine the effect of essential oil supplementation on the performance of broilers with regard to variable management conditions, including different stress factors, essential oils and their optimal dietary inclusion levels, active substances of oils, dietary ingredients and nutrient density. 


\section{References}

Alçiçek, A., Bozkurt, M. \& Çabuk, M., 2003. The effects of an essential oil combination derived from selected herbs growing wild in Turkey on broiler performance. S. Afr. J. Anim. Sci. 33, 89-94.

Alçiçek, A., Bozkurt, M. \& Çabuk, M., 2004. The effects of a mixture of herbal essential oil, an organic acid or a probiotic on broiler performance. S. Afr. J. Anim. Sci. 34, 217-222.

Anonymous, 1991. Animal feed-determination of metabolizable energy (chemical method). Turkish Standards Institute (TSE), Publ. No. 9610, 1-3.

Botsoglou, N.A, Christaki, E., Florou-Paneri, P., Giannenas, I., Papageorgiou, G. \& Spais, A.B., 2004. The effect of a mixture of herbal essential oils or á-tocopheryl acetate on performance parameters and oxidation of body lipid in broilers. S. Afr. J. Anim. Sci. 34, 52-61.

Denli, M., Okan, F. \& Uluocak, A.M., 2004. Effect of dietary supplementation of herb essential oils on the growth performance carcass and intestinal characteristics of quail (Coturnix coturnix japonica). S. Afr. J. Anim. Sci. 34, 174-179.

Dorman, H.J.D. \& Deans, S.G., 2000. Antimicrobial agent from plants: antimicrobial activity of plant volatile oils. J. Appl. Microbiol. 88, 308-316.

Gill, C., 1999. Herbs and plant extracts as growth enhancers. Feed Int. 20 (4), 20-23.

Halle, I., Thomann, R., Bauermann, U., Henning, M. \& Köhler, P., 2004. Effects of a graded supplementation of herbs and essential oils in broiler feed on growth and carcass traits. Landbauforshung Volkenrode 54, 219-229.

Hernandez, F., Madrid, J., Garcia, V., Orengo, J. \& Megias, M.D., 2004. Influence of two plant extracts on broiler performance, digestibility, and digestive organ size. Poult. Sci. 83, 169-174

Jamroz, D., Orda, J., Kamel, C., Wiliczkiewicz, A., Wertelecki, T. \& Skorupinska, J., 2003. The influence of phytogenetic extracts on performance, nutrient digestibility, carcass characteristics, and gut microbial status in broiler chickens. J. Anim. Feed Sci., 12, 583-596.

Jamroz, D., Wiliczkiewicz, A., Werteleck1, T., Orda, J. \& Sukorupinska, J., 2005. Use of active substances of plant origin in chicken diets based on maize and locally grown cereals. Br. Poult. Sci. 46, 485-493.

Langhout, P., 2000. New additives for broiler chickens. World Poultry-Elsevier 16 (3), 22-27.

Lee, K.W., Everest, H., Kappert, H.J., Yeom, K.H. \& Beynen, A.C., 2003. Dietary Carvacrol lowers body weight gain but improves feed conversion in female broiler chickens. Appl. Poult. Res. 12, 394-399.

Madrid, J., Hernandez, F., Garcia, V., Orengo, J., Magias, D. \& Savilla, V., 2003. Effect of plant extracts on ileal apparent digestibility and carcass yield in broilers at level of farm. $14^{\text {th }}$ European Symp. Poultry Nutrition. August 10-14, Norway. pp. 187-188.

Naumann, C. \& Bassler, R., 1993. Chemical Analyses of Feedstuff. Method Book III. (3rd ed.). VDLUFAPress. Darmstadt, Germany.

Norusis, M.J., 1993. Statistical Package for Social Science (SPSS) - Windows base System Users Guide (Release 6.0). SPSS, Chicago.

Peebles, E.D., Doyle, S.M., Pansky, T., Gerard, P.D., Latour, M.A., Boyle, C.R. \& Smith, T.W., 1999a. Effects of breeder age and dietary fat on subsequent broiler performance. 1. Growth, mortality, and feed conversion. Poult. Sci. 78, 505-511.

Peebles, E.D., Doyle, S.M., Pansky, T., Gerard, P.D., Latour, M.A., Boyle, C.R. \& Smith, T.W., 1999b. Effects of breeder age and dietary fat on subsequent broiler performance. 2. Slaughter yield. Poult. Sci. $78,512-515$.

Reis, L.H., Gama, L.T. \& Soares, M.C., 1997. Effects of short storage conditions and broiler breeder age on hatchability, hatching time and chick weights. Poult. Sci. 76, 1459-1466.

Sarica, S., Ciftci, A., Demir, E., Kilinc, K. \& Yıldırım, Y., 2005. Use of an antibiotic growth promoter and two herbal natural feed additives with and without exogenous enzymes in wheat based broiler diets. S. Afr. J. Anim. Sci. 35, 61-72.

Ultee, A., Kets, E.P.W. \& Smid, E.J., 1999. Mechanisms of action of carvacrol on the food borne pathogen Bacillus cereus. Appl. Environ. Microbiol. 65, 4606-4610.

Varel, V.H., 2002. Livestock manure odor abatement with plant-derived oils and nitrogen conservation with urease inhibitors: A review. J. Anim. Sci. 80 (2), E1-E7.

Zhang, K.Y., Yan, F., Keen, C.A. \& Waldroup, P.W., 2005. Evaluation of microencapsulated essential oils and organic acids in diets for broiler chickens. Int. J. Poult. Sci. 4 (9), 612-619. 